\title{
Article
}

\section{Integrated interpretive structural modeling (ISM) and MICMAC diagram for analysis of infrastructure influence in supporting submarine operations}

\author{
Moelyanto $^{1}$, Marsetio ${ }^{1}$, A. Octavian ${ }^{1}$, R.O. Bura ${ }^{1}$ and I. N. Putra ${ }^{1, *}$ \\ 1 Indonesia Defense University (IDU), Bogor, Jawa Barat 16810, Indonesia. \\ * Correspondence: nengahputra35@gmail.com
}

Received: 30 January 2021; Accepted: 17 August 2021; Published: 6 September 2021.

\begin{abstract}
The strategic value of the Navy's submarine capabilities is greatly influenced by the ability of its supporting infrastructure to be able to maintain the confidentiality of submarine operations. Based on these conditions, this study aims to identify and analyze the operational readiness of submarines to increase the deterrence of the state defense system at sea. This study uses Interpretive Structural Modeling (ISM) and MIC-MAC diagrams. The ISM method is used to analyze the effect on the criteria. MICMAC diagrams are used as criteria for determining the related variables. Based on the results of the ISM and MICMAC diagram analysis, it was found that fifteen elements were divided into 4 (four) quadrants. Quadrant I (Autonomous) consists of six elements, such as $\left(C_{1}\right),\left(C_{2}\right),\left(C_{3}\right),\left(C_{4}\right),\left(C_{13}\right),\left(C_{15}\right)$. Quadrant II (Dependent) consists of six elements, such as $\left(C_{5}\right),\left(C_{6}\right),\left(C_{7}\right),\left(C_{11}\right),\left(C_{12}\right),\left(C_{14}\right)$. Quadrant IV (Independent) consists of three elements, such as $\left(C_{8}\right),\left(C_{9}\right),\left(C_{10}\right)$. This research is expected to provide benefits to both academics and practitioners in the field of submarines and defense strategy.
\end{abstract}

Keywords: Interpretive structural modeling (ISM); MICMAC diagram; Submarine operations; Infrastructure.

\section{Introduction and Preliminaries}

$\mathbf{A}$ national defense system that has a deterrent power needs to be realized in the development of a defense force capable of protecting and ensuring the fulfillment of the national interests of the Indonesian nation (Ministry of Defence, 2015) [1]. As an archipelagic country with 2/3 of its territorial territory constituting the sea, it is necessary to carry out the development of Navy forces to realize a state defense system at sea [2].

The development of the naval force also needs to be carried out strategically and effectively to achieve the desired deterrence [3]. One of the effective forces to build deterrence in the country's defense strategy at sea is a submarine fleet. Due to the confidentiality, silence, and speed of a submarine that can paralyze a strategic maritime route (maritime chokepoint) and threaten the safety of shipping commercial vessels and naval vessels [4].

The strategic value of the Navy's submarine capabilities is greatly influenced by the ability of its supporting infrastructure to be able to maintain the confidentiality of submarine operations. However, infrastructure development supports the operational resilience of submarines in facing the limitations of the country's capabilities. Based on these conditions, this study aims to identify and analyze the operational readiness of submarines to increase the deterrence of the state defense system at sea. This study uses Interpretive Structural Modeling (ISM) and MIC-MAC diagrams. The ISM method is used to analyze the effect on the criteria. MICMAC diagrams are used as criteria for determining the related variables.

There are several previous texts in supporting research, namely A Maritime Research Concept through Establishing Ship Operational Problem Solution (Shipos) Centre via Information Technologies Integrated With or/Ms [5]. Determinants of Port Performance - Case Study of 4 Main Ports in Indonesia (2005-2015) [6]. Analysis of the Determinants of Micro Enterprises Graduation [7]. Determinants of Indonesian Crude Palm Oil Export: Gravity Model Approach [8]. ISM for analyzing interactions between barriers to just-in-time (JIT) production operations [9]. ISM to an analysis of core industry competencies in Pekalongan City [10]. ISM 
uses for identification of readiness in implementing Business Intelligence projects [11]. ISM to identify the drivers of travel/tourism growth and build relationships between enablers [12]. ISM to study various aspects and correlations between youth and sustainable rural development [13]. Navy Ability Development Strategy using SWOT Analysis-Interpretative Structural Modeling (ISM) [14].

This research is limited to the operational durability of submarines in Indonesia. This research is expected to provide benefits to both academics and practitioners in the field of submarines and defense strategy, Developing knowledge about the management of the national defense system.

This research consists of several parts. Section 2 describes ship operations during the state defense system, ISM method, MICMAC diagram, research stages, and research subjects \& objects. Section 3 describes the influence of variables in submarine operations and the classification of the distribution of these variables. Section 4 describes the conclusions in the study.

\section{Material \& Methods}

\subsection{State defense system at sea}

State defense aims to safeguard and protect the sovereignty of the country, the territorial integrity of the Republic of Indonesia, and the safety of the entire nation from all forms of threats and disturbances, both from outside and from within the country [15]. However, as a nation that has high-value national resources, vigilance is needed to continue to anticipate all forms of threats that are dynamic and can turn into real threats to ensure protection and fulfillment of national interests and to uphold national sovereignty (Ministry of Defence, 2015) [1].

Seapower is projected to control the use of marine areas, trade, and commerce at sea, as well as for deterrence, resistance at sea, defense diplomacy, and exerting political influence. The use of naval power is generally defined as the trinity of the role of maritime security forces which is manifested in the strength of a country's Navy [16].

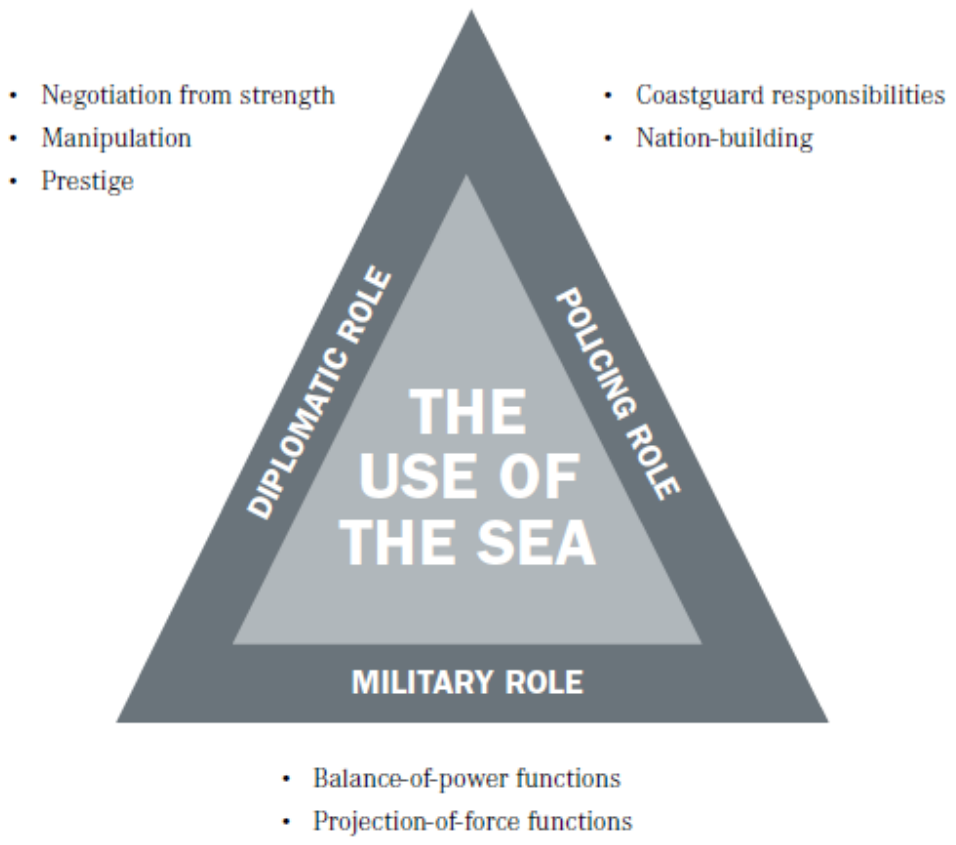

Figure 1. Ken booth trinity role

The Navy has a unique ability compared to other militaries, namely the ability to produce coercive signals and deterrence to the enemy. Naval power can effectively transmit these signals, and their effectiveness stems from two unique features of the Navy's capabilities. Referring to the nature and geographical conditions of 
the Indonesian nation, the development and development of the Navy's strength is a strategic policy analysis that needs attention in building a deterrent state defense system [17].

\subsection{Submarines as a state defense system}

In the context of national defense at sea, the strength of the Navy fleet is the domain in the formation, response, and preparation of all national resources to build a national defense system. The development of security and defense challenges at sea is currently felt to increasingly require the existence of a submarine fleet that is sufficient in quantity, modern technology, and operationally sustainable. The quantity aspect relates to the ideal number of submarines owned by a country. This number is greatly influenced by the size of the sea area owned by a country and the maritime defense strategy carried out by that country (Ministry of Defence, 2015) [1].

The submarine will be strategically connected to the command and control system where all warning and sensor systems will be the basis for providing command. The submarine fleet has certain advantages that surface warships do not have. Operational advantages include; can be used to bring troops into special operations fields; can be used to collect intelligence data as well as underwater surveys related to oil and natural gas mining sources; can be more effective in pursuing enemy warships during sea battles; as well as in terms of weaponry it is considered more accurate in carrying out subsurface and torpedo missile launches for both warships, submarines, and surface targets on land [18].

The strategic value of the submarine fleet can also be proven at an operational level that is not owned by surface warships or land and air warfare vehicles. These operational advantages include its ability to be used as a means of bringing troops into special operations in full confidence; can be used to collect intelligence data as well as underwater surveys related to oil and natural gas mining sources; can be more effective in destroying the strength of the enemy warship fleet during sea battles; as well as in terms of weaponry it is considered more accurate in carrying out subsurface and torpedo missile launches for both warships, submarines, and surface targets on land (Ministry of Defence, 2015) [1].

\subsection{Submarine operations}

The submarine is a unique water vehicle due to its ability to present strength in conventional and asymmetric warfare. This capability is achieved through its ability to maintain the confidentiality of the submarine's existence, which is related to the technology installed on the water vehicle. Determination of the technology that needs to be installed on a submarine generally considers the operational task to be carried out, the area of operation, the range of transit times, speed, diving depth, passive defense, weapon systems, rescue and rescue, re-support support, maintenance, and average size the crew [19].

The above technological factors can be broadly grouped into ship hull technology (platform), machinery system technology, propulsion system technology, navigation and communication system technology, and weapon systems technology. The sustainability of submarine operations is also determined by the technological aspects of the support equipment in the submarine maintenance and repair system owned by a country's navy. Submarine maintenance and repair support technology involves several main indicators, such as the submarine operation support logistics system, submarine maintenance and repair systems, and submarine operational financing systems [20].

Thus, the existence of supporting equipment technology, which includes a logistics system to support the submarine movement, policies related to the use, maintenance, and repair of submarines, as well as technical aspects which include the use of technology and submarine maintenance and repair facilities can be used as indicators key both in the framework of developing a strategy formula and implementing a sustainable submarine operational strategy [21].

\subsection{Interpretive structural modeling (ISM)}

Interpretive structural modeling (ISM) is used for ideal planning, which is an effective method because all elements can be processed in a simple matrix [22]. ISM was first proposed by Warfield in 1973. Interpretive structural modeling is a methodology that aims to identify the relationships between certain items, which define a related problem or issue [23], and modeling techniques suitable for analyzing the effect of one variable on another [24]. 
ISM is well-proven to identify structural relationships among system-specific variables. The basic idea is to use practical experience and expert knowledge to break down a complex system into sub-systems (elements) and build a multilevel structural model [25]. The ISM-based approach is one of the most versatile and powerful techniques that have been used to solve complex multi-factor problems. ISM is interpretive, in that the assessment of the group selected for research determines whether and how the variables are related [26]. ISM is often used to provide a fundamental understanding of a complex situation, as well as to construct a series of actions to solve a problem. There are procedures or stages in using the ISM method, these stages include [25]:

1. Parameter identification.

The elements to be considered for the identification of relationships were obtained through literature surveyors by conducting surveys.

2. Development of Structural Self Interaction Matrix (SSIM).

The development of the interpretive structural model begins with the construction of a structural self-interaction matrix, which shows the direction of contextual relationships among elements. In developing SSIM, the following four symbols have been used to indicate the direction of the relationship between two constraints $i$ and $j$.

3. Matriks Reachability. From the self-interaction matrix (SSIM), relational indicators are converted into binary numbers 0 and 1 to obtain a square matrix, which is called the reachability matrix [27].

- If $(i, j)$ the value in SSIM is $V,(i, j)$ the value in the reachability matrix will be 1 , and $(j, i)$ the value will be 0 .

- If $(i, j)$ the value in SSIM is $A,(i, j)$ the value in the reachability matrix will be 0 , and $(j, i)$ the value will be 1 .

- If $(i, j)$ the value in SSIM is $X,(i, j)$ the value in the reachability matrix will be 1 , and $(j, i)$ the value will also be 1.

- If $(i, j)$ the value in SSIM is the value of $O,(i, j)$ in the reachability matrix will be 0 , and $(j, i)$ will also be 0 .

4. Partition level.

From the reachability matrix, for each parameter, the reachability set and the antecedent set are derived. Variables, which are common in reachability sets and antecedent sets, are allocated to intersection sets. Once the upper-level barrier is identified, it is removed from consideration, and other upper-level barriers are found [25]. This process will continue until all levels of each barrier are found.

5. Interpretive structural modeling constructs (ISM).

From the partitioned parameters and reachability matrix, the structured model is derived, showing the parameters at each level and arrows showing the direction of the relationship.

Table 1. SSIM symbol rules

\begin{tabular}{c|c} 
Symbol & Relationship Between Element Row (i) and Column (j) \\
\hline $\mathrm{V}$ & $\begin{array}{r}\text { There is a contextual relationship between the } E_{i} \text { element and the } \\
E_{j} \text { element, but it is not the other way around. }\end{array}$ \\
\hline $\mathrm{A}$ & There is a contextual relationship between the element $E_{j}$ and the element $E_{i}$, but not vice versa. \\
\hline $\mathrm{X}$ & There is a reciprocal contextual relationship between $E_{i}$ elements and $E_{j}$ elements. \\
\hline $\mathrm{O}$ & There is no reciprocal contextual relationship between element $E_{i}$ and element $E_{j}$.
\end{tabular}

\section{MIC-MAC Diagram}

MICMAC analysis refers to Matrice d'Impacts Croisés Multiplication Appliquée á un Classement (Hussain, 2011) and involves developing a graph to classify the various enablers based on their driving power and dependence power. MICMAC is also used to check driving power and power dependence so that later it can be identified which elements are the keys to driving the system being analyzed. The variables have been classified into four categories referred to as Autonomous, Linkage, Dependent and Driving/independent. 
Table 2. Samples on the reachability matrix

\begin{tabular}{c|c|c|c|c|c|c|c|c}
$(\mathbf{j})$ & \multicolumn{10}{|c}{} \\
(i)Enablers & $\mathbf{1}$ & $\mathbf{2}$ & $\mathbf{3}$ & $\mathbf{4}$ & $\mathbf{5}$ & $\mathbf{6}$ & $\mathbf{7}$ & $\mathbf{8}$ \\
\hline 1 & 1 & 1 & 0 & 0 & 0 & 0 & 0 & 0 \\
\hline 2 & 0 & 1 & 1 & 0 & 0 & 0 & 0 & 0 \\
\hline 3 & 1 & 1 & 1 & 1 & 1 & 1 & 1 & 0 \\
\hline 4 & 1 & 1 & 1 & 1 & 1 & 1 & 1 & 0 \\
\hline 5 & 1 & 1 & 1 & 1 & 1 & 1 & 1 & 0 \\
\hline 6 & 1 & 1 & 1 & 1 & 1 & 1 & 1 & 0 \\
\hline 7 & 1 & 1 & 1 & 1 & 1 & 1 & 1 & 0 \\
\hline 8 & 1 & 1 & 1 & 1 & 1 & 1 & 1 & 1
\end{tabular}

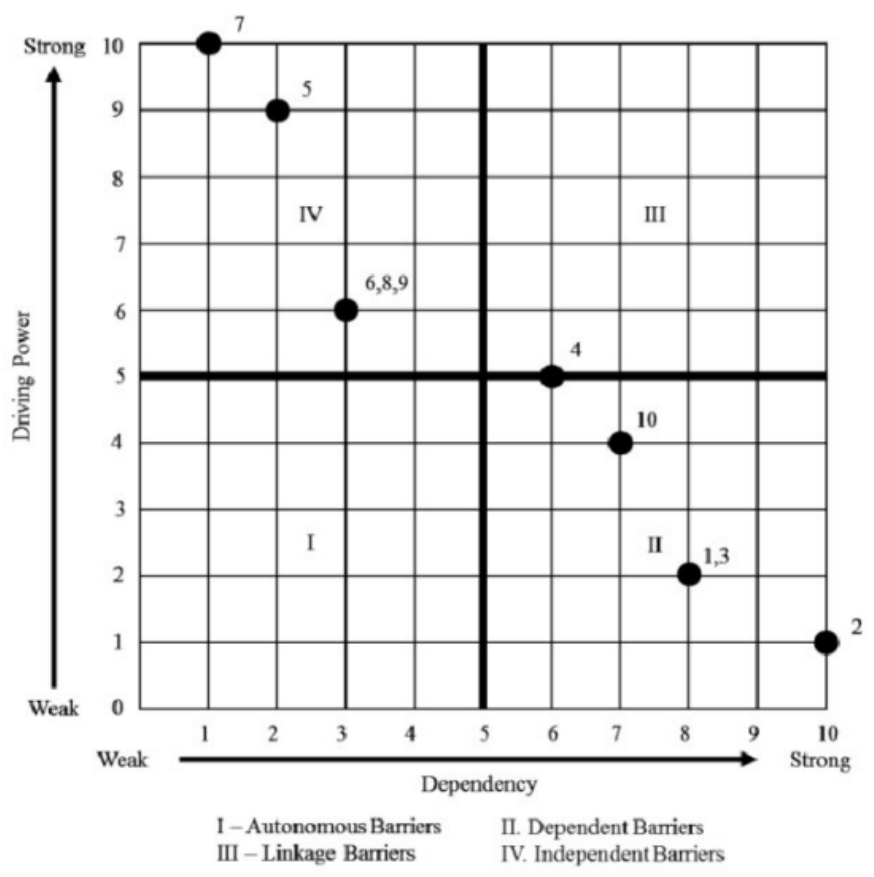

Figure 2. MIC-MAC Diagram.

\subsection{Research Subject and Obyek}

The object of this research is the operational resilience of the submarine. Submarine operational resilience is defined as the ability of a submarine to be in the area of operation without being noticed by other parties in conditions of diving (diving depth), diving periscope (periscope depth), or sailing on the surface.

Indicators used to collect data from resource persons about the influence of various conditions (the system in the submarine, the mode of sailing during operation, physical and psychological readiness of the crew, availability of operational budgets, and the development of the strategic environment of the Indonesian nation) on the operational durability of the submarine.

\subsection{Research subject}

Research subjects or respondents are parties who are used as samples in a study. The research subject also discusses the characteristics of the subject used in the study, including an explanation of the population, sample, and sampling technique used. In this study, the sources of research were experts, including 1) Vice Admiral Muhammad Ali; 2) Marx Jefferson; 3) Vice Admiral (Rtr) Rachmad Lubis; 4) Vice Admiral Iwan Isnurwanto; 5) Vice Admiral TNI Tunggul Suropati. 
Table 3. SSIM symbol rules

\begin{tabular}{c|c|c|c} 
No. & Expert & Total & Code \\
\hline 1 & Commander of First Fleet Command, Vice Admiral Muhammad Ali & 1 & $E_{1}$ \\
\hline 2 & Head of the Submarine Program of PT PAL Indonesia, Marx Jefferson & 1 & $E_{1}$ \\
\hline 3 & $\begin{array}{c}\text { Head of the KKIP Technology Transfer and Offset Division, } \\
\text { Vice Admiral (Rtr) Rachmad Lubis }\end{array}$ & 1 & $E_{3}$ \\
\hline 4 & Vice Admiral Iwan Isnurwanto & 1 & $E_{4}$ \\
\hline 5 & Vice Admiral TNI Tunggul Suropati & 1 & $E_{5}$
\end{tabular}

The object of research is essentially the topic of the problem understudy in the research. The object of research is essentially the topic of the problem understudy in the research. In this study, the object of research is the durability of submarine operations in Indonesia.

\subsection{Goal}

In this study, the target is the influence of the existing criteria and classify them in the variables contained in submarine operational durability.

\section{Flow diagram.}

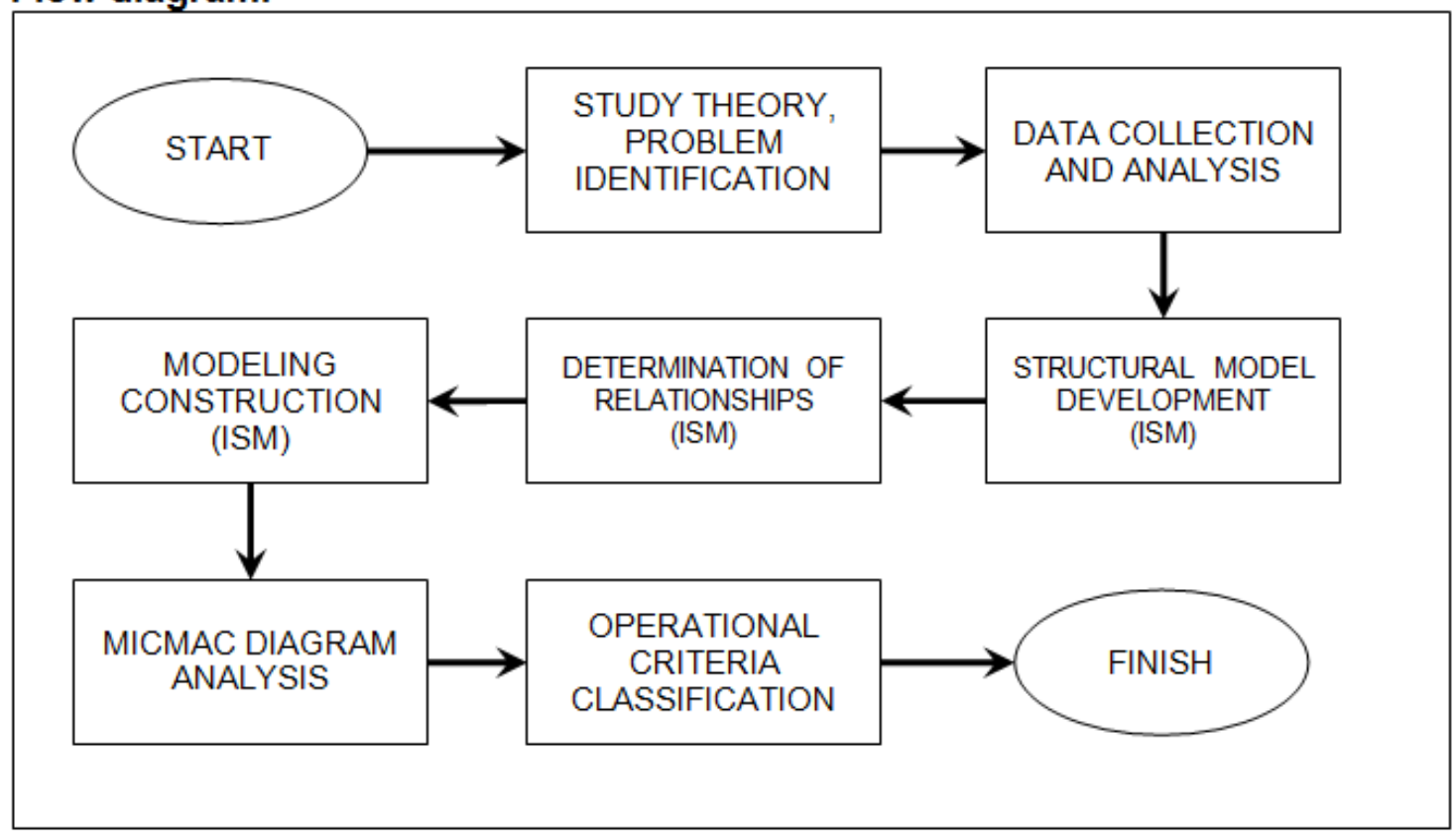

Figure 3. Research flowchart

\section{Results}

The data collected from the questionnaires were compiled in the research database used in the subsequent data analysis process. After the data was collected, the research instrument was tested to obtain confidence that each question item was able to accurately and accurately be used as a variable measuring tool.

The submarine operational survival variable is measured (observable variables) through indicators fuel tank capacity; freshwater tank capacity; submarine battery capacity; air regeneration system capacity; sail with surface mode/periscope depth / operational depth; operating area wave conditions; the physical properties of the water column (temperature, salinity, depth); crew physical readiness; the psychic readiness of the crew; Operating budget; Operation pattern; Strategic Environment Development Conditions. 
Table 4. Elements of Ketahanlamaan Operasional Kapal Selam

\begin{tabular}{c|c} 
Code & Criteria \\
\hline$C_{1}$ & Fuel Tank Capacity \\
\hline$C_{2}$ & Fuel Tank Capacity \\
\hline$C_{3}$ & Submarine Battery Capacity \\
\hline$C_{4}$ & Air Regeneration System Capacity \\
\hline$C_{5}$ & Sail With Surface Mode \\
\hline$C_{6}$ & Sail With A Periscope Depth \\
\hline$C_{7}$ & Sail With Operational Depth \\
\hline$C_{8}$ & Operating Area Wave Conditions \\
\hline$C_{9}$ & Current conditions of the operating area \\
\hline$C_{10}$ & The Physical Properties Of The Water Column (Temperature, Salinity, Depth) \\
\hline$C_{11}$ & Crew Physical Readiness \\
\hline$C_{12}$ & The Psychic Readiness Of The Crew \\
\hline$C_{13}$ & Operating Budget \\
\hline$C_{14}$ & Operation Pattern \\
\hline$C_{15}$ & Strategic Environment Development Conditions
\end{tabular}

The second step, application of identified criteria or variables that are defined in pairs. Then with SSIM, paired relationships are developed between the factors that affect the system. The association matrix is evaluated by SSIM and used for transitivity within the ISM. Next, factorization was carried out on the related criteria. Data recapitulation of interconnection between strategies is analyzed in the Structural Self Interaction Matrix (SSIM) by converting numbers into letters that represent the categories of relationships. At this stage, a contextual relationship is made between variable $i$ and variable $j$. Next, review the contextual relationship in the form of the SSIM-VAXO Matrix.

Table 5. Results of the structural self interaction matrix (SSIM) analysis

\begin{tabular}{c|c|c|c|c|c|c|c|c|c|c|c|c|c|c|c|c}
\multirow{2}{*}{ No } & Code & \multicolumn{10}{c|}{ Factorization } \\
\hline & & 15 & 14 & 13 & 12 & 11 & 10 & 9 & 8 & 7 & 6 & 5 & 4 & 3 & 2 & 1 \\
\hline 1 & $\mathrm{C}_{1}$ & $\mathrm{O}$ & $\mathrm{A}$ & $\mathrm{A}$ & $\mathrm{O}$ & $\mathrm{O}$ & $\mathrm{O}$ & $\mathrm{O}$ & $\mathrm{O}$ & $\mathrm{V}$ & $\mathrm{V}$ & $\mathrm{V}$ & $\mathrm{O}$ & $\mathrm{O}$ & $\mathrm{O}$ & \\
\hline 2 & $\mathrm{C}_{2}$ & $\mathrm{O}$ & $\mathrm{O}$ & $\mathrm{V}$ & $\mathrm{O}$ & $\mathrm{O}$ & $\mathrm{V}$ & $\mathrm{O}$ & $\mathrm{O}$ & $\mathrm{V}$ & $\mathrm{V}$ & $\mathrm{V}$ & $\mathrm{O}$ & $\mathrm{O}$ & & \\
\hline 3 & $\mathrm{C}_{3}$ & $\mathrm{O}$ & $\mathrm{V}$ & $\mathrm{O}$ & $\mathrm{O}$ & $\mathrm{O}$ & $\mathrm{O}$ & $\mathrm{O}$ & $\mathrm{O}$ & $\mathrm{V}$ & $\mathrm{V}$ & $\mathrm{V}$ & $\mathrm{O}$ & & & \\
\hline 4 & $\mathrm{C}_{4}$ & $\mathrm{O}$ & $\mathrm{O}$ & $\mathrm{O}$ & $\mathrm{O}$ & $\mathrm{V}$ & $\mathrm{X}$ & $\mathrm{O}$ & $\mathrm{O}$ & $\mathrm{V}$ & $\mathrm{V}$ & $\mathrm{V}$ & & & & \\
\hline 5 & $\mathrm{C}_{5}$ & $\mathrm{O}$ & $\mathrm{A}$ & $\mathrm{O}$ & $\mathrm{V}$ & $\mathrm{V}$ & $\mathrm{A}$ & $\mathrm{A}$ & $\mathrm{A}$ & $\mathrm{X}$ & $\mathrm{X}$ & & & & & \\
\hline 6 & $\mathrm{C}_{6}$ & $\mathrm{O}$ & $\mathrm{O}$ & $\mathrm{O}$ & $\mathrm{A}$ & $\mathrm{A}$ & $\mathrm{A}$ & $\mathrm{A}$ & $\mathrm{X}$ & $\mathrm{X}$ & & & & & & \\
\hline 7 & $\mathrm{C}_{7}$ & $\mathrm{O}$ & $\mathrm{A}$ & $\mathrm{O}$ & $\mathrm{V}$ & $\mathrm{V}$ & $\mathrm{A}$ & $\mathrm{A}$ & $\mathrm{A}$ & & & & & & & \\
\hline 8 & $\mathrm{C}_{8}$ & $\mathrm{O}$ & $\mathrm{V}$ & $\mathrm{O}$ & $\mathrm{V}$ & $\mathrm{V}$ & $\mathrm{X}$ & $\mathrm{X}$ & & & & & & & & \\
\hline 9 & $\mathrm{C}_{9}$ & $\mathrm{~A}$ & $\mathrm{~V}$ & $\mathrm{O}$ & $\mathrm{V}$ & $\mathrm{V}$ & $\mathrm{A}$ & & & & & & & & & \\
\hline 10 & $\mathrm{C}_{10}$ & $\mathrm{O}$ & $\mathrm{V}$ & $\mathrm{O}$ & $\mathrm{O}$ & $\mathrm{O}$ & & & & & & & & & & \\
\hline 11 & $\mathrm{C}_{11}$ & $\mathrm{O}$ & $\mathrm{V}$ & $\mathrm{A}$ & $\mathrm{X}$ & & & & & & & & & & & \\
\hline 12 & $\mathrm{C}_{12}$ & $\mathrm{O}$ & $\mathrm{A}$ & $\mathrm{A}$ & & & & & & & & & & & & \\
\hline 13 & $\mathrm{C}_{13}$ & $\mathrm{~A}$ & $\mathrm{X}$ & & & & & & & & & & & & & \\
\hline 14 & $\mathrm{C}_{14}$ & $\mathrm{~A}$ & & & & & & & & & & & & & & \\
\hline 15 & $\mathrm{C}_{15}$ & & & & & & & & & & & & & & &
\end{tabular}

In the second stage, the reachability matrix table is generated by the symbols $\mathrm{V}, \mathrm{O}, \mathrm{A}$, and $\mathrm{X}$ to become binary 1 and 0 , with the following conditions:

- If relation $(i, j)$ is denoted as $\mathrm{V}$, then input $(i, j)$ in $\mathrm{RM}$ becomes 1 , and input $(j, i)$ becomes 0 .

- If relation $(i, j)$ is denoted as $\mathrm{A}$, then input $(i, j)$ in RM becomes 0 , and input $(j, i)$ becomes 1 .

- If the relation $(i, j)$ is denoted as $X$, then input $(i, j)$ in $\mathrm{RM}$ becomes 1 , and input $(j, i)$ becomes 1 .

- If the relation $(i, j)$ is denoted as $\mathrm{O}$, then input $(i, j)$ in RM becomes 0 , and input $(j, i)$ becomes 0 . 
Table 6. Results of the reachability matrix

\begin{tabular}{|c|c|c|c|c|c|c|c|c|c|c|c|c|c|c|c|c|c|}
\hline \multirow{2}{*}{ No. } & \multirow{2}{*}{ Code } & \multicolumn{15}{|c|}{ Factorization } & \multirow{2}{*}{ DP } \\
\hline & & 1 & 2 & 3 & 4 & 5 & 6 & 7 & 8 & 9 & 10 & 11 & 12 & 13 & 14 & 15 & \\
\hline 1 & $C_{1}$ & 1 & 0 & 0 & 0 & 1 & 1 & 1 & 0 & 0 & 0 & 0 & 0 & 0 & 0 & 0 & 4 \\
\hline 2 & $C_{2}$ & 0 & 1 & 0 & 0 & 1 & 1 & 1 & 0 & 0 & 1 & 0 & 0 & 1 & 0 & 0 & 6 \\
\hline 3 & $C_{3}$ & 0 & 0 & 1 & 0 & 1 & 1 & 1 & 0 & 0 & 0 & 0 & 0 & 1 & 0 & 0 & 5 \\
\hline 4 & $C_{4}$ & 0 & 0 & 0 & 1 & 1 & 1 & 1 & 0 & 0 & 1 & 1 & 0 & 0 & 0 & 0 & 6 \\
\hline 5 & $C_{5}$ & 0 & 0 & 0 & 0 & 1 & 1 & 1 & 0 & 0 & 0 & 1 & 1 & 0 & 0 & 0 & 5 \\
\hline 6 & $C_{6}$ & 0 & 0 & 0 & 0 & 1 & 1 & 1 & 1 & 0 & 0 & 0 & 0 & 0 & 0 & 0 & 4 \\
\hline 7 & $C_{7}$ & 0 & 0 & 0 & 0 & 1 & 1 & 1 & 0 & 0 & 0 & 1 & 1 & 0 & 0 & 0 & 5 \\
\hline 8 & $C_{8}$ & 0 & 0 & 0 & 0 & 1 & 1 & 1 & 1 & 1 & 1 & 1 & 0 & 0 & 1 & 0 & 9 \\
\hline 9 & $C_{9}$ & 0 & 0 & 0 & 0 & 1 & 1 & 1 & 1 & 1 & 0 & 1 & 0 & 0 & 1 & 0 & 8 \\
\hline 10 & $C_{10}$ & 0 & 0 & 0 & 1 & 1 & 1 & 1 & 1 & 1 & 1 & 0 & 0 & 0 & 1 & 0 & 8 \\
\hline 11 & $C_{11}$ & 0 & 0 & 0 & 0 & 0 & 1 & 0 & 0 & 0 & 1 & 1 & 1 & 0 & 1 & 0 & 5 \\
\hline 12 & $C_{12}$ & 0 & 0 & 0 & 0 & 0 & 1 & 0 & 0 & 0 & 1 & 1 & 1 & 0 & 0 & 0 & 4 \\
\hline 13 & $C_{13}$ & 1 & 0 & 0 & 0 & 0 & 0 & 0 & 0 & 0 & 0 & 1 & 1 & 1 & 1 & 0 & 5 \\
\hline 14 & $C_{14}$ & 1 & 0 & 0 & 0 & 1 & 1 & 0 & 0 & 0 & 0 & 0 & 1 & 1 & 1 & 0 & 6 \\
\hline 15 & $C_{15}$ & 0 & 0 & 0 & 0 & 0 & 0 & 0 & 0 & 1 & 0 & 0 & 0 & 1 & 1 & 1 & 4 \\
\hline Dep & dence & 3 & 1 & 1 & 2 & 11 & 13 & 10 & 4 & 4 & 6 & 8 & 8 & 5 & 7 & 1 & \\
\hline
\end{tabular}

\subsection{MICMAC Analysis}

The next step is to arrange a hierarchy of each sub-element in the element being studied and classify it into four sectors, whether these sub-elements are included in the Autonomous, Dependent, Linkage or Independent sectors, namely:

1. Quadrant-I: weak driver-weak dependent variables (Autonomous), which means that the sub-elements that enter this sector are generally not related to the system and may have a little relationship even though the relationship can be strong.

2. Quadrant - II: weak driver-strongly dependent variables (dependent) which means that the sub-elements in this sector are dependent.

3. Quadrant - III: strong driver-strongly dependent variables (linkage), which means that the sub-elements that enter this sector must be studied carefully because the relationship between the sub-elements is unstable.

4. Quadrant - IV: Strong driver-weak dependent variables (Independent), which means that the sub-elements that enter this sector are the remaining parts of the system which are called independent variables.

Table 7. Driving power \& dependence

\begin{tabular}{c|c|c|c|c|c|c|c|c|c|c|c|c|c|c|c} 
& $C_{1}$ & $C_{4}$ & $C_{3}$ & $C_{4}$ & $C_{5}$ & $C_{6}$ & $C_{7}$ & $C_{8}$ & $C_{9}$ & $C_{10}$ & $C_{11}$ & $C_{12}$ & $C_{13}$ & $C_{14}$ & $C_{15}$ \\
\hline $\mathbf{X}$ & 3 & 1 & 1 & 2 & 11 & 13 & 10 & 4 & 4 & 6 & 8 & 8 & 5 & 7 & 1 \\
\hline $\mathbf{Y}$ & 4 & 6 & 5 & 6 & 5 & 4 & 5 & 9 & 8 & 8 & 5 & 4 & 5 & 6 & 4
\end{tabular}

The result of the MICMAC diagram analysis classifies the elements into four sectors in a two-dimensional graph with the $x$ (dependence) and $y$ (powder driver) axes.

Based on Figure 4, obtained several classifications of submarine operational durability elements. These elements are divided into four classifications, namely:

- Quadrant - I (Autonomous) consists of six elements, namely: a) Fuel tank capacity $\left(C_{1}\right)$; b) Freshwater tank capacity $\left(C_{2}\right)$; c) Submarine battery capacity $\left(C_{3}\right)$; d) Air regeneration system capacity $\left(C_{4}\right)$; e) Operating budget $\left(C_{13}\right)$; f) Strategic Environment Development Condition $\left(C_{15}\right)$.

- Quadrant - II (Dependent) consists of six elements, namely: a) Sailing in surface mode $\left(C_{5}\right)$; b) Sailing with periscope depth $\left(C_{6}\right)$; c) Sailing with operational depth $\left(C_{7}\right)$; d) Crew Physical Readiness $\left(C_{11}\right)$; e) The Psychic Readiness Of The Crew $\left(C_{12}\right)$; f) Operation pattern $\left(C_{14}\right)$. 
- Quadrant - III (Linkage) there are no elements.

- Quadrant - IV (Independent) consists of three elements, namely: a) Operating area wave conditions $\left(C_{8}\right)$; b) Current conditions in the operating area $\left(C_{9}\right)$; c) Physical properties of the water column (temperature, salinity, depth) $\left(C_{10}\right)$.

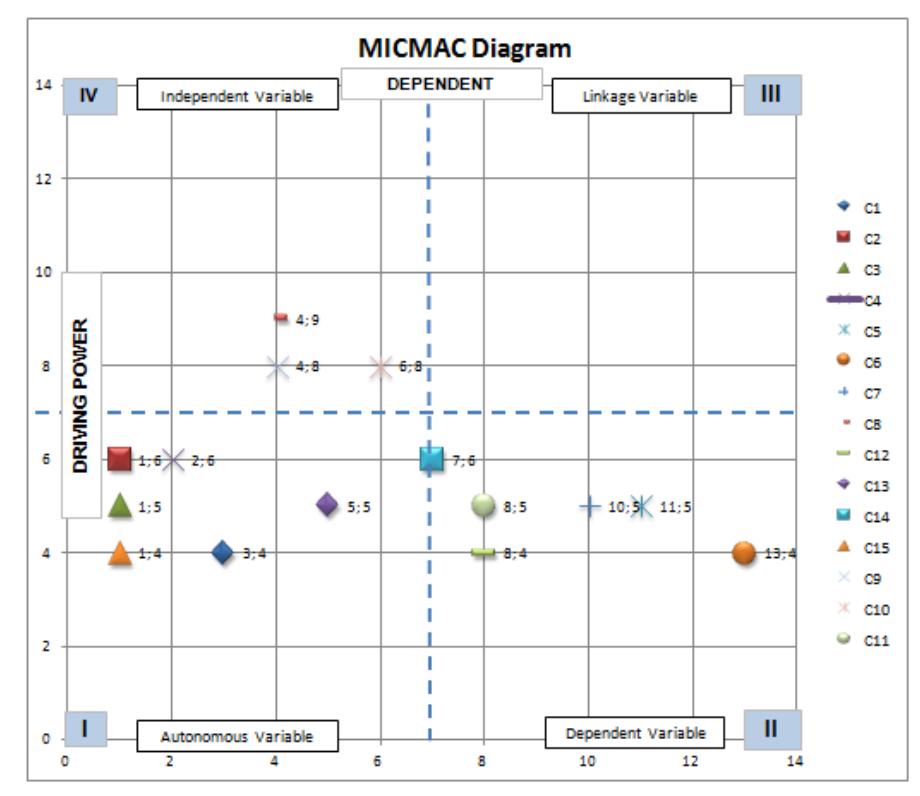

Figure 4. MICMAC diagram analysis results

\section{Conclusion}

This study aims to identify and analyze the operational readiness of submarines to increase the deterrence of the state defense system at sea. Based on the research results, there are several classifications of submarine operational durability elements. Based on the results of the ISM and MICMAC diagram analysis, it was found that fifteen elements were divided into 4 (four) quadrants, likely Quadrant I (Autonomous) consists of six elements, namely: a) Fuel tank capacity $\left(C_{1}\right)$; b) Freshwater tank capacity $\left(C_{2}\right)$; c) Submarine battery capacity $\left(C_{3}\right)$; d) Air regeneration system capacity $\left(C_{4}\right)$; e) Operating budget $\left(C_{13}\right)$; f) Strategic Environment Development Condition $\left(C_{15}\right)$. Quadrant II (Dependent) consists of six elements, namely: a) Sailing in surface mode $\left(C_{5}\right)$; b) Sailing with periscope depth $\left(C_{6}\right)$; c) Sailing with operational depth $\left(C_{7}\right)$; d) Crew Physical Readiness $\left(C_{11}\right)$; e) The Psychic Readiness Of The Crew $\left(C_{12}\right)$; f) Operation pattern $\left(C_{14}\right)$. Quadrant IV (Independent) consists of three elements, namely: a) Operating area wave conditions $\left(C_{8}\right)$; b) Current conditions in the operating area $\left(C_{9}\right)$; c) Physical properties of the water column (temperature, salinity, depth) $\left(C_{10}\right)$.

\section{Future Work}

There are advised in research that can be used for future research, among others:

- As advised to carry out an analysis of operational durability using the Structural Equation Model (SEM) method.

- As advised, an evaluation analysis of current submarine operational policies can be carried out.

- As further research, a submarine operational strategy concept can be made following the development of the industrial revolution 4.0 and naval technology 2030.

Acknowledgments: This Research is supported by Indonesia Defense University. We also thank all parties who support this research.

Author Contributions: All authors contributed equally to the writing of this paper. All authors read and approved the final manuscript.

Conflicts of Interest: "The authors declare no conflict of interest." 


\section{References}

[1] Ministry of Defence, T. R. (2015). Indonesian Defence White Paper. Jakarta: Ministry of Defence of the Republic of Indonesia.

[2] Yogi, P., Rizal, O., Ahmadi, \& Suharyo, O. S. (2017). Feasibility analysis of naval base relocation using SWOT and AHP method to support main duties operation. Journal of Defense Management, 7(1), 1-8.

[3] Bowers, I. (2017). Power asymmetry and the role of deterrence in the South China sea. The Korean Journal of Defense Analysis, 29(4), 551-573.

[4] Agastia, I. G. (2017). Small navy, big responsibilities: The struggles of building Indonesia's naval power. AEGIS, I(II), 164-180.

[5] Soner, O., Akyuz, E., \& Celik, M. (2015). A maritime research concept through establishing ship operational problem solution (Shipos) centre via information technologies integrated with or/Ms. Procedia-Social and Behavioral Sciences, 195, 2796-2803.

[6] Aqmarina, A., \& Achjar, N. (2017). Determinants of Port Performance-Case Study of 4 Main Ports in Indonesia (2005-2015). Economics and Finance in Indonesia, 63(2), 176-185.

[7] Ascarya, \& Rahmawati, S. (2018). Analysis of the determinants of micro enterprises graduation. Journal of Islamic Economics, Banking and Finance, 14(1), 12-39.

[8] Ridwannulloh, R., \& Sunaryati, S. (2018). The determinants of Indonesian crude palm oil export: Gravity model approach. Jurnal Ekonomi \& Studi Pembangunan, 19(2), 134-141.

[9] Jadhav, J. R., Mantha, S. S., \& Rane, S. B. (2015). Analysis of interaction among the barriers to JIT production: Interpretative structural modeling approach. Journal of Industrial Engineering International, 11, 331-352.

[10] Paramitha, F., \& Nurcahyo, R. (2018, January). Industrial strategy development of core competence in Pekalongan City. In Proceedings of the International Conference on Industrial Engineering and Operations Management (pp. 1556-1565).

[11] Farrokhi, V., Pokorádi, L., \& Bouini, S. (2018). The identification of readiness in implementating business intelligence projects by combining interpretive structural modeling with graph theory and matrix approach. Acta Polytechnica Hungarica, 15(2), 89-102.

[12] Roy, S., \& Misra, S. (2016). Interpretative structural modeling (ISM) of tratvel and tourism enablres. Specialty Journal of Psychology and Management, 2(2), 32-45.

[13] Panackal, N., \& Singh, A. (2016). Using interpretative structural modeling to determine the relation between youth and sustainable rural development. Journal of Management and Research, 4(1), 58-64.

[14] Susilo, A. K., Ciptomulyono, U., Putra, I. N., Ahmadi, \& Suharyo, O. S. (2019). Navy ability development strategy using swot analysis-interpretative structural modeling (ISM). Strategic Management, 24(1), 30-40.

[15] Laksmana, E. A. (2014). Rebalancing Indonesia's naval force. Dalam Naval Modernisation in South-East Asia: Nature, Causes and Consequences (hal. 175-203). London: Routledge.

[16] Marsetio. (2013). Strategi TNI Angkatan Laut dalam Pengamanan Batas Maritim NKRI: Kajian Historis-Strategis. Jurnal Sejarah Citra Lekha, XVII(1), 1-18.

[17] Holmes, J. R. (2013). Why hold an international fleet review ?: Insights from Ken Booth. Proceedings of the Royal Australian Navy Sea Power. Canberra: Sea Power Centre - Australia.

[18] Caldwell, D., Freda, J., \& Goldstein, L. J. (2020). China Maritime Repor China Maritime Report No. 5: China t No. 5: China's Dreadnought? The PL eadnought? The PLA Navy's Type 055 Cruiser and Its Implications for the F Type 055 Cruiser and Its Implications for the Future Maritime Security Environment . Newport: U.S. Naval War College.

[19] Krepinevich, A. F. (2014). Maritime Competition in A Mature Precision-Strike Regime. Center for Strategic and Budgetary Assessments.

[20] Kuseian, J. (2013). Naval Power Systems Technology Development Roadmap. Electric Ship Office.

[21] Nawara, T. M. (2013). Resource constrained scheduling problem at U.S. Naval Shipyards. Massachussetts: Calhoun.

[22] Wang, M. T. (2015). Use of a Combination of AHP and ISM for Making an Innovative Rescue Caring Design in Landslide Area. Mathematical Problems in Engineering, 1-13.

[23] Attri, R., Dev, N., \& Sharma, V. (2013). Interpretative structural modelling (ISM) approach: An overview. Research Journal of Management Sciences, 2(2), 3-8.

[24] Agarwal, A., Shankar, R., \& Tiwari, M. K. (2007). Modeling agility of supply Chain. Industrial Marketing Management, $36(4), 443-457$.

[25] Firoz, N., \& Rajesh, R. (2012). Relationship among supplier selection criteria using interpretative structural modeling for manufacturing organization in Kerala. International Journal of Engineering Science Invention, 3(8), 60-70.

[26] Soti, R. S., \& Kaushal, O. P. (2010). Modeling the enablers of six sigma using interpreting structural modeling. Journal of Modeling in Management, 5(2), 124-141. 
[27] Hussain, M. (2011). Modelling the Enablers and Alternatives for Sustainable Supply Chain Management. Montreal: Concordia University.

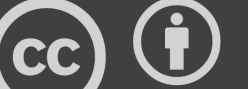

BY

(C) 2021 by the authors; licensee PSRP, Lahore, Pakistan. This article is an open access article distributed under the terms and conditions of the Creative Commons Attribution (CC-BY) license (http://creativecommons.org/licenses/by/4.0/). 